Institute of $\mathbf{F}_{\text {ood and }} \mathbf{A}_{\text {gricultural }} \mathbf{S}_{\text {ciences }}$

\title{
Using Nematodes to Control Insects: Overview and Frequently Asked Questions ${ }^{1}$
}

William T. Crow ${ }^{2}$

Nematodes are unsegmented roundworms, different from earthworms and other familiar worms that are segmented (annelids) or in some cases flattened and slimy (flatworms). Nematodes are the most abundant animals on the planet. It is estimated that 4 of every 5 multicellular organisms are nematodes. Different nematodes inhabit almost every environment on earth, ranging from the ocean floors to swamps, deserts, and polar ice caps.

Usually the first encounter people have with nematodes is when their crop, prized plant, pet, or child gets sick from one or more types of parasitic nematodes. However, of the estimated 1 to 20 million species of nematodes less than $1 \%$ are harmful. Most nematodes feed on bacteria, fungi, and microscopic organisms. Certain nematodes can be used to kill unwanted insect pests. Several species of these nematodes are mass-produced and sold commercially. They are sometimes called "insect pathogenic," "insect parasitic," "entomopathogenic," or sometimes just "beneficial" nematodes. We will use the term "biological control nematodes" to describe them here. Our objective is to give information on these nematodes, clear up some common misconceptions, and outline how they can be used.

\section{How do biological control nematodes work?}

All biological control nematodes have an infective stage (called third-stage juvenile or daur larvae) that will enter into the insect host. The nematodes usually enter the insect through its breathing holes, mouth, or anus (Figure 1), but some species are capable of penetrating thin areas of the insect's cuticle. After they enter the insect's body the nematodes release special bacteria into the insect. These bacteria are only found associated with the biological control nematodes. The toxins produced by the bacteria kill the insect after a few days. The bacteria multiply inside the body of the insect and the nematodes eat the bacteria. The nematodes mature, mate, and multiply inside the insect. Eventually, the insect's body becomes filled with nematodes (Figure 2). Infective stage nematodes then exit the insect body in search of other insects to infect (Figure 3).

1. This document is ENY-050, one of a series of the Entomology \& Nematology Department, Florida Cooperative Extension Service, Institute of Food and Agricultural Sciences, University of Florida. Publication date: December 2002. For more publications related to horticulture/agriculture, please visit the EDIS Website at http://edis.ifas.ufl.edu/.

2. William T. Crow, assistant professor, Entomology \& Nematology Department, Cooperative Extension Service, Institute of Food and Agricultural Sciences, University of Florida, Gainesville, 32611.

The Institute of Food and Agricultural Sciences is an equal opportunity/affirmative action employer authorized to provide research, educational information and other services only to individuals and institutions that function without regard to race, color, sex, age, handicap, or national origin. For information on obtaining other extension publications, contact your county Cooperative Extension Service office. Florida Cooperative Extension Service/Institute of Food and Agricultural Sciences/University of Florida/Christine Taylor Waddill, Dean. 


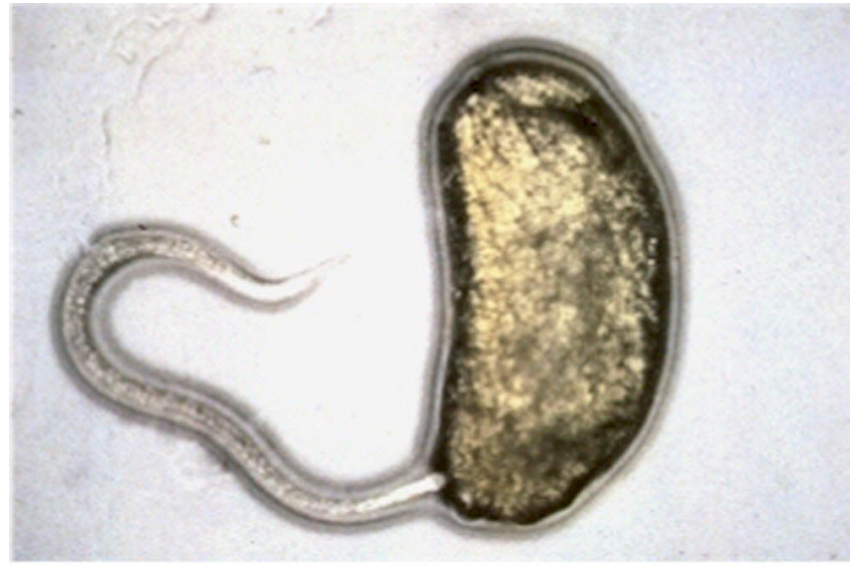

Figure 1. A biological control nematode entering the anus of an insect larvae. Credits: L. LeBeck, University of Hawaii

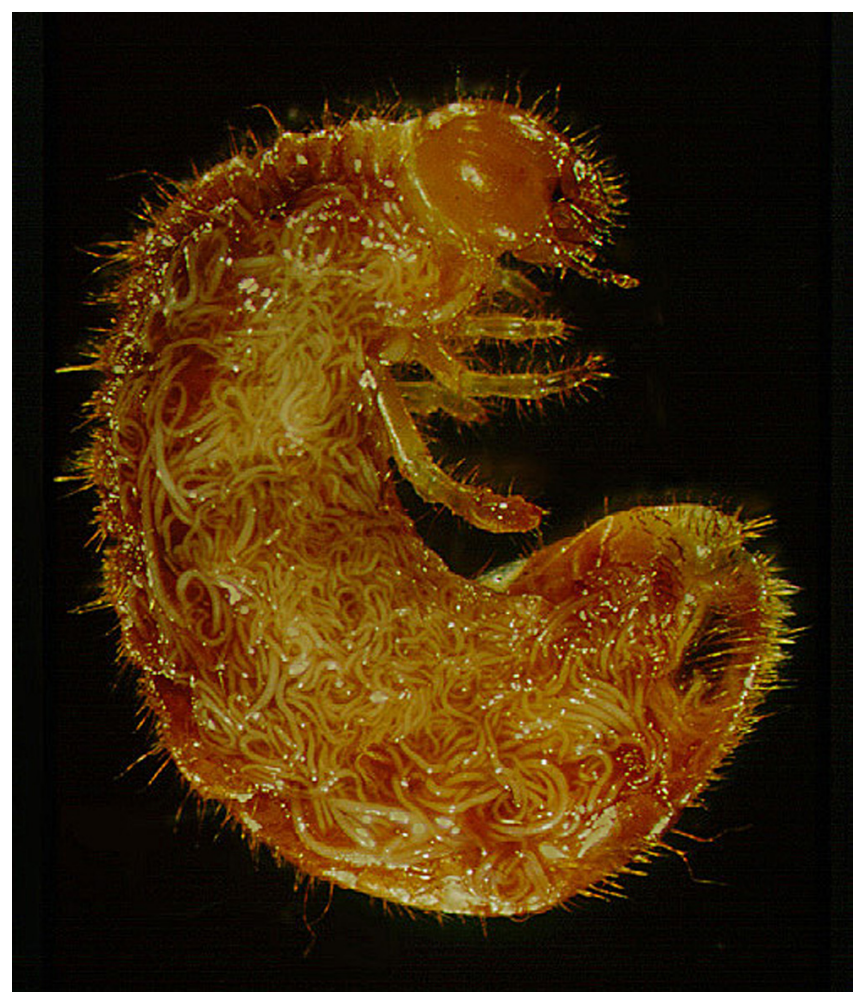

Figure 2. A beetle grub that is filled with biological control nematodes. Credits: R. Gaugler, Rutgers University

\section{What is the difference between biological control nematodes and insect-parasitic nematodes?}

There are nematodes that are insect parasites, but the nematodes that are sold commercially are not parasites. True parasites feed from their host. However, biological control nematodes feed on the bacteria, and the bacteria are the true parasites. There are species of nematodes that are true insect parasites.

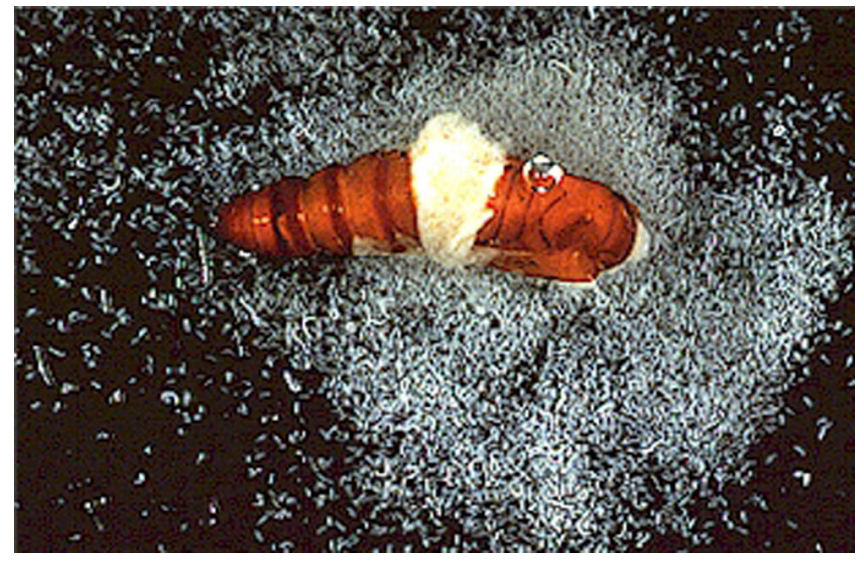

Figure 3. Biological control nematodes leaving the body of a dead insect to find another host to infect. Credits: R. Gaugler, Rutgers University

Some examples are mermithid nematodes that parasitize grasshoppers (Figure 4), cockroaches, and mosquitoes. You might see these when you squash a cockroach in your home. These nematodes can play a part in natural suppression of pest insects. But, because they only feed on their insect hosts, they must be raised in live insects. This is not a very efficient means of production. Biological control nematodes can be raised in vats and fed with bacteria, so they are much easier to produce.

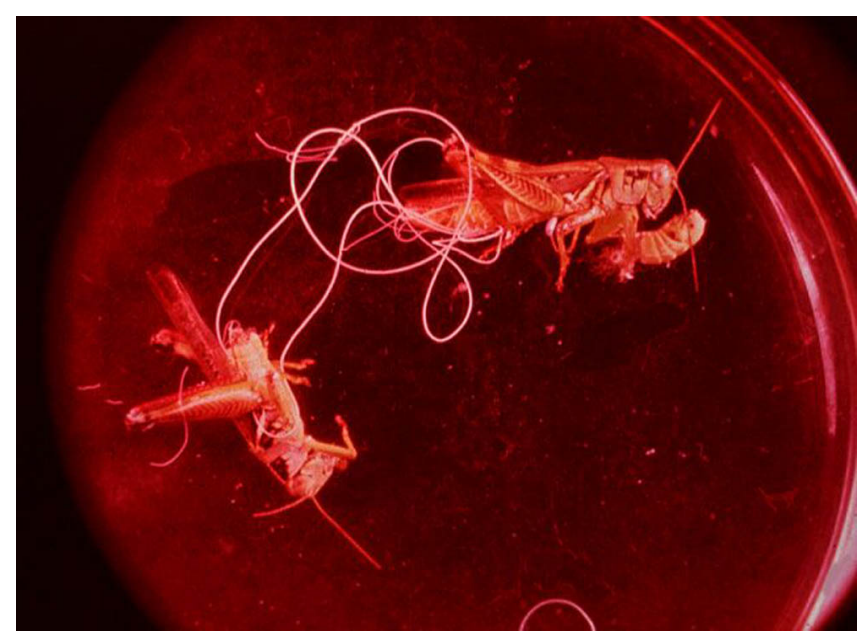

Figure 4. These nematodes (Agamermis sp.), from the body of a grasshopper, are true insect-parasitic nematodes. Credits: Society of Nematologists photo collection.

\section{Can biological control nematodes be used for many types of insects?}

Not all species of biological control nematodes are equally effective at managing different species of insect pests. The ability of any biological control 
nematode to infect a particular insect can be affected by nematode and insect behavior, physical barriers, and immune responses.

Different species of biological control nematodes find their insect hosts in different ways. Some biological control nematodes move actively through the soil in search of an insect. They are attracted to the insect by chemicals it releases. These nematodes can be called "cruisers" because they search out the host (Figure 5). Other species of biological control nematodes stay still and wait for the insect to move to them. These nematodes stand on their tails (nictate) (Figure 5). When the insect crawls by the nematode can "jump" onto it. Because these species lie in wait for their host, they can be called "ambushers."

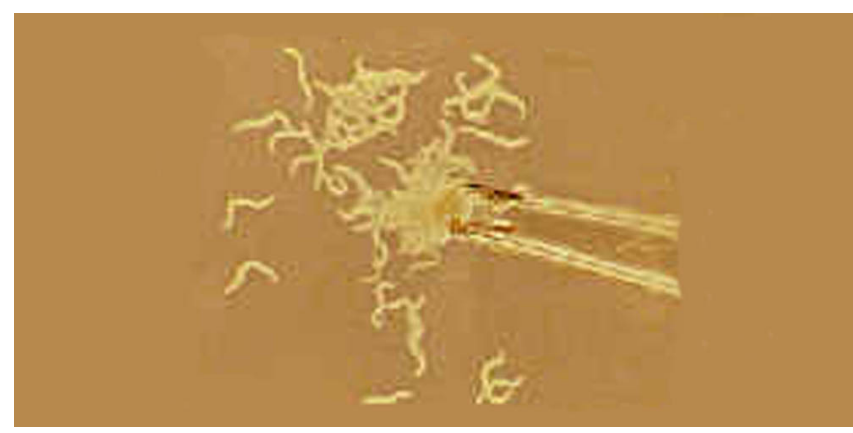

Figure 5. "Cruiser" types of biological control nematodes are attracted by carbon dioxide released by insects. These nematodes are being attracted by carbon dioxide coming through a glass pipette tip. Credits: R. Gaugler, Rutgers University

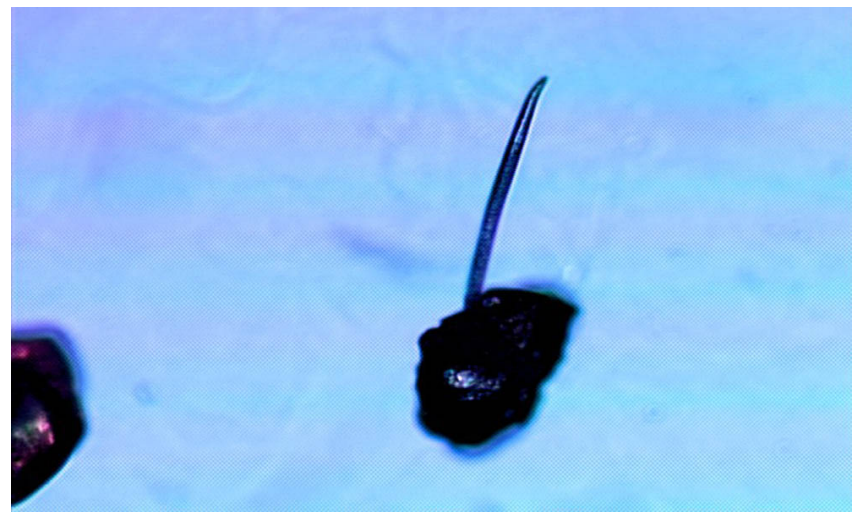

Figure 6. This "ambusher" type nematode is standing on it's tail (nictating) as it waits for an insect to come by. Credits: R. Gaugler, Rutgers University

Because cruiser nematodes seek out their host, they are most effective against insects that do not move very much. Cruiser nematodes would not be able to catch up with rapidly moving insects. Because grubs move very slowly, they are good targets for biological control using nematodes that are cruisers.

Ambusher nematodes, on the other hand, are more effective on mobile insects. A slow moving insect would not be likely to contact an ambusher nematode. Mole-crickets are an example of a mobile insect that can be managed with ambusher-type nematodes.

Some insects are not good hosts to certain species of biological control nematodes because they have physical barriers or immune responses that prevent infection. For example, an insect might have very small breathing holes that would not allow a large nematode to enter, but a smaller species of nematode might enter the holes easily. Certain insects have hard plates that cover their breathing holes that prevent nematode entry. Finally, some insects can have an immune response that helps protect them from nematodes.

\section{What insects can be managed by nematodes?}

Research has shown certain biological control nematodes to be helpful in managing several common pests in Florida including mole-crickets and some grubs. Clearly, it is very important to select the right nematode to use on a particular insect. Table 1 has a list of commercially available nematodes and the insects that they have been shown to be most affective against. Do not purchase nematodes if the species is not known. The better distributors should be able to tell you what nematode species they sell.

\section{How about ants and termites?}

There are several companies marketing biological control nematodes for use against ants and termites. Despite many of the claims, there is no clear evidence that use of biological control nematodes is particularly effective against these social insects. In most cases the insects can simply move to avoid the nematodes or groom the nematodes off of each other. 


\section{Where do I purchase biological control nematodes?}

It is best to order biological control nematodes and have them delivered directly to you from the manufacturer. This helps insure that the nematodes you are buying are still alive. Nematodes do not live very long in storage. Therefore, buying nematodes that are stocked on a store shelf is risky. A list of commercially available biological control nematodes and their distributors is given in "Biological control nematodes: Suppliers and pesticide compatibility" available on-line or at your local Cooperative extension office (http://edis.ifas.ufl.edu/ng008).

\section{Can biological control nematodes be harmful?}

Because many people have heard of nematodes harming their plants or animals, they may be concerned about "putting" nematodes out in their landscape (http://edis.ifas.ufl.edu/ng006). They need have no fear. These nematodes can only feed on their bacteria. They cannot feed on, live in, or harm humans, plants, or animals. The only danger could be if someone has an allergic reaction to the nematodes.

Nematodes that feed on plants have a stylet (mouth-spear) that they use to puncture plant cells (Figure 7). Nematodes cannot feed on plants without a stylet. Biological control nematodes do not have a stylet, but rather have an open mouth for eating bacteria (Figure 8 ).

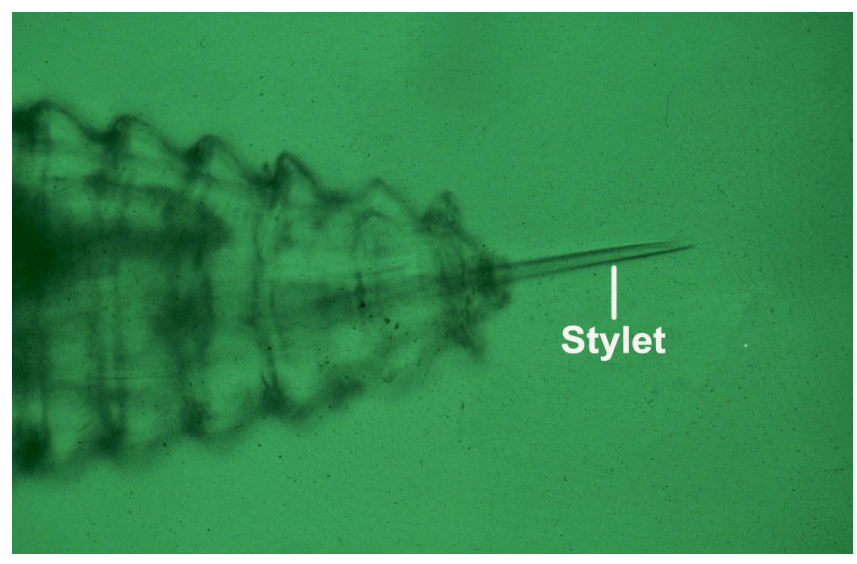

Figure 7. The mouth of a nematode that feeds on plants has a stylet (spear) that they use to puncture plant cells. Credits: R. A. Dunn, University of Florida

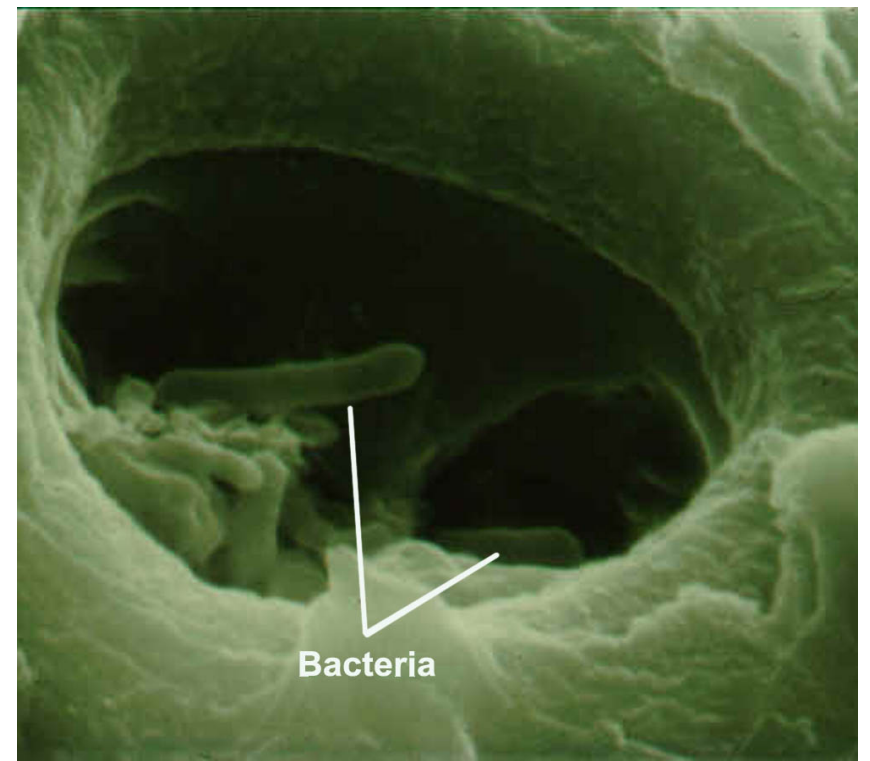

Figure 8. The mouth of a biological control nematode has no stylet, but is open for swallowing bacteria. Credits: R. Gaugler, Rutgers University

\section{How often do I need to use biological control nematodes?}

Contrary to what you may hear, in most cases biological control nematodes do not persist for a long time after they are applied. Most of these nematodes can live for only a few weeks at most without their host insect. Biological control nematodes occur naturally in most environments. They kill a few insects and help reduce insect epidemics. If they killed off all of their host insects, the nematodes would die off too. When we apply commercially available biological control nematodes, we are attempting to overload the natural system and kill many more insects than would be killed by nematodes naturally. If the treatment is successful, and most of the pest insects die, the nematode populations decline as well. Soon the natural balance is restored. When insect populations begin to build back up another nematode application is required.

\section{What are some tips for using biological control nematodes?}

1) Use them as soon as possible after they arrive. Remember, the nematodes must be alive to work and they die off during prolonged storage.

2) Store them in a cool place until use. Most species should be refrigerated, but some need higher 
temperatures. Check with the manufacturer for the optimal storage temperature. The nematodes are in a dormant state while they are cool. If they get warm they will become more active and die quicker. Also, do not let them freeze as that can kill them.

3) Do not expose them to heat or sunlight. Heat kills nematodes rapidly. Nematodes are also sensitive to U.V. light from the sun.

4) Early morning or evening is usually the best time to apply them. During light rain can also be a good time. These are times when it is cool and light intensity is low.

5) Water the soil before and after you apply nematodes. Nematodes need water to move and survive. The water will also help get the nematodes into the ground out of the sunlight, and to where the insects are.

6) Some pesticides may harm the nematodes. See "Biological control nematodes: Suppliers and pesticide compatibility," available on-line (http://edis.ifas.ufl.edu/ng008) or at your local Cooperative extension office, for a list of pesticides to be avoided.

\section{Will I see the insects die?}

Probably not. One of the reasons some people like to use hard pesticides is the psychological gratification from seeing the dead insects and knowing they have killed them. In most cases, nematodes will attack and kill the insects under the ground. You will usually not see dead insects laying on top of the ground.

\section{So, how will I know if they worked?}

There is an element of faith involved. You have to watch and trust that they are working. However, if after a few days the insect damage continues to get worse, additional applications of nematodes, or use of other management tools may be required. Visit your local Cooperative Extension office for recommendations on pest management or view the University of Florida Insect Management Guide on-line at http://edis.ifas.ufl.edu/ TOPIC_GUIDE_Insect_Management_Guide.

\section{What are some other sources of information?}

Your local Cooperative Extension office should have information pertinent to your area. Additional information from the University of Florida is available on-line at http://edis.ifas.ufl.edu/TOPIC_Beneficial_Nematodes . Taxonomic information on biological control nematodes by the University of Florida is available at http://kbn.ifas.ufl.edu/kbnstein.htm. An excellent website on biological control nematodes through the Ohio State University can be viewed at http://www2.oardc.ohio-state.edu/nematodes/. 
Table 1. Current Use of Nematodes as Biological Insecticides

\begin{tabular}{|c|c|c|}
\hline Commodity & Insect Pest & Nematode Species \\
\hline Artichokes & Artichoke plume moth & S. carpocapsae \\
\hline Berries & Root weevils & H. bacteriophora \\
\hline Citrus & Root weevils & S. riobrave \\
\hline \multirow[t]{2}{*}{ Cranberries } & Root weevils & H. bacteriophora, S. carpocapsae \\
\hline & Cranberry girdler & S. carpocapsae \\
\hline Mushrooms & Sciarids & S. feltiae \\
\hline \multirow[t]{3}{*}{ Ornamentals } & Root weevils & H. bacteriophora, H. megidis \\
\hline & Wood borers & S. carpocapsae, H. bacteriophora \\
\hline & Fungus gnats & S. feltiae \\
\hline \multirow[t]{4}{*}{ Turf } & Scarabs & H. bacteriophora \\
\hline & Mole crickets & S. riobrave, S. scapterisci \\
\hline & Billbugs & H. bacteriophora, S. carpocapsae \\
\hline & Armyworm, Cutworm, Webworm & S. carpocapsae \\
\hline
\end{tabular}

